\title{
SELF ESTEEM TERHADAP SUBJECTIVE WELL BEING PADA BURUH SOPIR PENGANGKUT PETI KEMAS
}

\author{
Windy Febi Aulia \\ Mahasiswa Sekolah Tinggi Ilmu Psikologi Abdi Nusa Palembang \\ Jalan Veteran No. 1 Palembang \\ Surel :-winnwindi@yahoo.co.id
}

\begin{abstract}
This study aims to determine whether or not there is a relationship between self esteem and subjective well being on driver workers in container transportation PT. Tri Trans Wijaya Palembang. The population of this study is all container driver PT. Tri Trans Wijaya Palembang totaling 46 people. The data collection tool used in this study is the scale of self esteem and the scale of subjective well being. This analysis using correlation techniques from Pearson's product moment. The researcher didn't use sample techniques but used populat ion techniques because the population was 46 container drivers PT. Tri Trans Wijaya which all the drivers become the subject of this study. The results from this study showed that there was a positive relationship between Subjective Well Being and self esteem in container drivers PT. Tri Trans Wijaya Palembang. This relationship is indicated by the r-count correlation coefficient of 0,375 and $r$ table of 0.291. Thus r-count $>$-table. This result informs that the more precisely self esteem, the higher the subjective well being will be, and vice versa. The conclusion in this study showed there is a relationship between self esteem and subjective well being on on driver workers in container transportation PT. Tri Trans Wijaya.
\end{abstract}

Keywords: Self esteem, Subjective well being, Chauffeur

\begin{abstract}
Abstrak : Penelitian ini bertujuan untuk mengetahui ada tidaknya hubungan antara antara self esteem dengan subjective well being pada buruh sopir pengangkut peti kemas PT. Tri Trans Wijaya Palembang. Populasi penelitian ini adalah seluruh buruh sopir peti kemas PT. Tri Trans Wijaya Palembang yang berjumlah 46 orang. Alat pengumpulan data yang digunakan dalam penelitian ini adalah Skala self esteem dan Skala subjective well being. Analisis dengan menggunakan teknik korelasi dari product moment dari pearson. Pada penelitian ini, peneliti tidak menggunakan teknik sampel akan tetapi menggunakan teknik populasi di karenakan populasi berjumlah 46 orang buruh sopir peti kemas PT. Tri Trans Wijaya yang semuanya dijadikan subjek penelitian. Dari penelitian ini di peroleh hasil yang menunjukkan bahwa terdapat hubungan positif antara self esteem dengan Subjective Well Being pada buruh sopir peti kemas PT. Tri Trans Wijaya Palembang. Hubungan tersebut ditunjukkan dengan ditujukan dengan koefisien korelasi rhitung sebesar 0,375 dan r-tabel 0,291. Dengan demikian r-hitung > r-tabel. Hasil ini menginformasikan bahwa semakin tepatnya self esteem maka akan semakin tinggi pula subjective well being tersebut, demikian pula sebaliknya.

Kesimpulan dalam penelitian ini adalah ada hubungan antara self esteem dengan subjective well being pada buruh sopir peti kemas PT. Tri Trans Wijaya.
\end{abstract}

Kata kunci: Harga Diri, Kesejahteraan Subjektif, Buruh sopir

Self Esteem terhadap Subjective Well Being pada Buruh.......(Windy Febi Aulia) 


\section{PENDAHULUAN}

Kebahagian merupakan segala sesuatu keadaan yang dirasakan oleh setiap orang yang sifatnya berbeda menurut pandangan satu orang dan orang lainnya. Bisa jadi satu orang menganggap apa yang ia rasakan merupakan kebahagiaan yang sesungguhnya, namun bisa jadi hal tersebut berbeda dengan yang lainnya. Kebahagiaan terdiri dari tiga dimensi yaitu dimensi kepuasan hidup, dimensi perasaan dan dimensi makna hidup.

Menurut Siedlecki, Salthouse, Oishi, dan Jeswani (2013) mengatakan bahwa seseorang memiliki hubungan yang memuaskan dapat memperoleh dukungan ketika mereka membutuhkannya, sedangkan mereka yang tidak memiliki hubungan yang memuaskan tidak dapat dengan mudah memperoleh dukungan ketika mereka membutuhkannya.

Dalam kehidupan sehari-hari, kebanyakan orang menganggap bahwa peristiwa kehidupan utama seperti pernikahan atau pengangguran memiliki efek luar biasa pada kebahagiaan (Brickman dan Campbell, 1971). Menikah atau bercerai, kehilangan kekayaan, dipekerjakan, dipecat. Peristiwa harus mempengaruhi tingkat subjective wellbeing selama lebih dari beberapa bulan karena orang beradaptasi dengan cepat dan tak terhindarkan terhadap perubahan kehidupan apapun. (Luhmann, Eid, and Lucas, 2012).

Kepuasan setiap orang, emosi, dan penilaian evaluatif diri sendiri memunculkan waktu kerja. Meskipun masing-masing komponen subjective wellbeing mencerminkan evaluasi orang terhadap apa yang terjadi dalam kehidupan mereka, aspek subjective well-being seperti pengaruh positif, kurangnya pengaruh negatif, dan kepuasan hidup menunjukkan beberapa derajat kemandirian (Andrews dan Withey 1976) dan karenanya harus diukur dan dipelajari secara individual.

Banyak penulis populer, telah menafsirkan genetiknya bukti yang berarti bahwa kebahagiaan ditentukan oleh DNA. Ini bukan untuk menjadi alasan, seperti Diener, Oishi dan Lucas (2003) berpendapat di beberapa tempat. Pertama, paling banyak studi genetika, ada cukup banyak variabilitas dalam kebahagiaan dari waktu ke waktu. Subjective well-being mereka bergerak naik dan turun seiring waktu sebagai reaksi terhadap peristiwa kehidupan. Peneliti biasanya menemukan bahwa lingkungan keluarga awal (kembar tumbuh di rumah yang sama) memiliki pengaruh pada tingkat pengaruh positif bahwa pengalaman kembar sebagai orang dewasa. Dengan kata lain, sesuatu tentang 
keluarga bersama lingkungan di masa kanak-kanak mempengaruhi individu untuk kemudian merasa kurang atau lebih emosi positif, seperti sukacita, antusiasme, dan keterlibatan. (Eid dan Larsen, 2008).

Penilaian suatu kesejahteraan pada masyarakat miskin menjadi penting untuk diperhatikan agar pemerintah mampu mengetahui apakah rakyatnya merasa sejahtera atau sebaliknya yang nantinya akan menjadi acuan dalam menanggulangi masalah kemiskinan. diketahui bahwa manusia merupakan makluk yang memiki ciri khas masing- masing dan memiliki cara pandang dan batas ideal tersendiri dalam menilai hidupnya.

Berdasarkan data yang diambil dari Badan Pusat Statistik (BPS) pada tahun 2017, berdasarkan hasil Survei Pengukuran Tingkat Kebahagiaan (SPTK) sebesar 70,69 pada skala 0-100 yaitu kepuasan hidup dengan besaran kontribusi sebesar 34,80 persen, perasaan dengan besaran kontribusi sebesar 34,02 persen. Nilai indeks masing-masing dimensi indeks kebahagiaan adalah indeks dimensi kepuasan hidup 71,07, indeks dimensi perasaan sebesar 68,59 dan indeks dimensi makna hidup sebesar 72,23. Artinya semakin mendekati 100 akan semakin bagus atau bisa dikatakan indeks kebahagian tahun 2017 cukup bahagia. Indeks kebahagian tersebut berdasarkan klasifikasi wilayah, jenis kelamin, status perkawinan dan kelompok umur. Dan data tersebut juga mengungkapkan bahwa orang yang belum menikah memiliki angka indeks kebahagiaan tertinggi dari status perkawinan lainnya.

$$
\text { Menurut Winarsih }
$$
mengungkapkan bahwa kebahagiaan ada dua yaitu kebahagiaan yang bersifat objektif dan subjektif. Kebahagiaan objektif diukur dengan menggunakan sebuah standar sedangkan kebahagiaan subjektif tidak didasarkan pada ketentuan manapun, melainkan mengacu pada masing-masing pribadi, sehingga pada setiap orang dapat berbeda.

Kebahagiaan subjektif ini disebut pula subjective well-being atau kesejahteraan subjektif yang merupakan sinonim kebahagiaan. Angka bunuh diri di ASEAN oleh WHO pada tahun 2012, Indonesia menduduki peringkat ke delapan setelah Thailand, Myanmar, Kamboja, Singapura, Laos, Brunei, dan Vietnam dengan kasus bunuh diri 3,7 per 100.000 populasi, yang artinya prevalensi lebih rendah dibandingkan negara-negara Asia lainnya. Namun dengan 258 juta penduduk, berarti ada 10.000 bunuh diri di Indonesia tiap tahun atau satu orang per jam. Bunuh diri menjadi penyebab utama kedua kematian pada usia 15-29 tahun. Bunuh 
diri terjadi sebanyak 75\% kasus bunuh diri (Statistik Kesehatan Dunia 2016).

Data-data diatas yang dapat disimpulkan adalah Indonesia mempunyai penduduk dengan subjective well-being yang rendah seperti memandang rendah hidupnya dibandingkan dengan tujuh negara ASEAN lainnya dan menganggap peristiwa yang terjadi sebagai hal yang tidak menyenangkan. Mereka gunakan untuk bunuh diri adalah menelan pestisida, gantung diri dan menggunakan senjata api

Menurut Eryilmaz (2014), meskipun sejarah studi tentang bagaimana individu meningkatkan tingkat subjective well being dalam psikologi. Situasi dan peristiwa yang dialami oleh orang dapat menciptakan subjective well being rendah atau tinggi untuk individu. Namun pada waktunya, efek yang dibuat mulai kehilangan kekuatan mereka. Ketika individu beradaptasi dengan kondisi positif atau negatif, keadaan subjective well being mereka pada tingkat tinggi dan keadaan subjective well being padatingkat rendah tidak berlangsung lama

Tingginya tingkat subjective wellbeing pada orang dewasa diharapkan membuat remaja menjadi individu yang lebih positif sehingga dewasa menjadi lebih sehat secara mental. Dewasa yang sehat mampu meminimalisir dampak negatif dari perubahan biologis, psikologis, sosial dan kognitif sertaa pengaruh lingkungan urban pada dirinya. Oleh sebab itu maka penelitian terhadap subjective well-being bagi dewasa menjadi penting apalagi untuk orang yang mempunyai penghasilan yang tidak terlalu besar namun mempunyai tanggung jawab yang sangat besar. Konsep Self esteem ada di mana-mana dalam kehidupan kontemporer.

Self esteem sangat penting untuk sukses dalam aspek tersebut. Memang mempromosikan diri dan mencegah Self esteem yang rendah, dianggap sebagai tujuan penting masyarakat luas dan bermanfaat untuk meningkatkan tingkat intervensi Self esteem dalam populasi. (Orth and Robins, 2014)

Menurut Baumeister (1993) bahwa Self esteem dikonseptualisasikan sebagai penilaian dari Self esteem seseorang. Tidak ada kekurangan cara untuk mendefinisikan harga diri. Mungkin yang paling sederhana ditemukan dalam kamus Webster, yang mengatakan bahwa kepuasan harga diri dengan diri sendiri yang berkaitan dengan nilai-nilai, keyakinan dan sikap yang kita pegang tentang diri kita sendiri. Harga diri yang sederhana adalah penerimaan kita untuk siapa dan apa kita pada waktu tertentu dalam hidup kita (Srivastava dan Joshi, 2014). 
Harga diri didasarkan pada bagaimana perasaan kita ketika kita melihat ke cermin atau berbicara tentang diri kita sendiri. Harga diri dapat mengetahui bahwa kita layak mencintai dan menghormati serta menerima keterbatasan dan batasan kita (Donellan, Trzesniewski dan Conger, 2007).

Peneliti sangat tertarik dengan fenomena self esteem pada perusahaan ini, karena self esteem itu sendiri dapat diartikan dengan keyakinan nilai diri sendiri berdasarkan evaluasi diri secara keseluruhan. Perasaan-perasaan self esteem, pada kenyataannya terbentuk oleh keadaan kita dan bagaimana orang lain memperlakukan kita.

Self esteem diukur dengan pernyataan positif maupun negatif. Pernyataan positif pada survey self esteem adalah diri individunya merasa sangat berarti, seperti orang lainnya, sedangkan pernyataan-pernyataan yang negatif adalah diri individunya merasa bahwa tidak memiliki banyak hal untuk dibanggakan.

Self esteem yang tinggi membuat seseorang memiliki beberapa kelebihan termasuk pemahaman mengenai arti dan nilai hidup. Hal itu merupakan pedoman yang berharga dalam hubungan interpersonal dan merupakan hasil alamiah dari pertumbuhan seseorang yang sehat. Sehingga hal tersebut dapat menjadikannya menjadi lebih dapat mengenali tentang lingkungan sekitarnya yang akan membuat buruh merasakan kepuasan akan kehidupannya dan merasakan emosi yang positif.

\section{METODOLOGI PENELITIAN}

Penelitian ini menggunakan penelitian kuantitatif korelasional yang bertujuan untuk mengetahui hubungan antara dua variabel. Penelitian ini akan dilakukan di PT. Tri Trans Wijaya Palembang yang berlokasi di Jl. Sikam Lrg Sikam 1 Kalidoni Palembang. Waktu penelitian ini akan dilakukan selama bulan Mei sampai Juni 2019. Dengan urutan rencana kegiatan mulai dari observasi, wawancara, dokumentasi data serta pembagian angket pada buruh sopir pengangkutan peti kemas yang bertujuan untuk mencari informasi tentang hubungan Self esteem dengaan Subjective Well-Being pada buruh sopir pengangkutan peti kemas.

Populasi itu sendiri adalah wilayah generalisasi yang terdiri atas obyek dan subyek yang mempunyai kualitas dan karakteristik tertentu yang ditetapkan oleh peneliti untuk dipelajari kemudian ditarik kesimpulannya (Sugiyono, 2015). Sampel yang digunakan sebanyak 46 buruh sopir.

Pengumpulan data dalam penelitian ini dilakukan dengan melakukan metode skala. Metode ini digunakan mengingat 
variabel-variabel dalam penelitian ini yaitu Subjective well-being dan Self Esteem, metode skala yaitu suatu metode pengumpulan data yang berisikan sejumlah data yang berisi daftar pernyataan yang tertulis yang disebarkan kepada responden dengan maksud mendapatkan informasi mengenai sesuatu masalah yang ingin diselidiki.

Instrument pengumpulan data yang digunakan dalam penelitian ini terdiri dari skala likert. Skala Subjective well-being dan Self Esteem. Respon yang diharapkan diberikan oleh subyek adalah taraf kesetujuan atau tidak kesetujuan dalam bentuk kategori, sangat tidak sesuai (STS), dapat lebih mudah untuk diungkap dengan

tidak sesuai (TS), sesuai (S), sangat sesuai (SS).

\section{HASIL DAN PEMBAHASAN}

Uji hipotesis yang berguna untuk mengetahui apakah hipotesis yang diajukan dapat diterima atau tidak. Ha pada penelitian ini berbunyi terdapat hubungan antara self esteem terhadap subjective well being, sedangkan Ho berbunyi tidak terdapat hubungan antara antara self esteem terhadap subjective well being. Dari hasil analisis analisis koelasi product moment person. Diperoleh koefisien determinansi sebesar 0,375 dengan nilai signifikansi $0,01 \quad(p<0,05)$ dengan ada hubungan yang siginifikan antara self esteem terhadap subjective well being

\section{Tabel 1. Hasil Uji Hipotesis}

\begin{tabular}{|c|c|c|c|}
\hline & 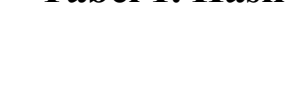 & Self Esteem & $\begin{array}{l}\text { Subjective } \\
\text { Well Being }\end{array}$ \\
\hline \multirow[t]{3}{*}{ Self Esteem } & Pearson Correlation & 1 & $.375 *$ \\
\hline & Sig. (2-tailed) & & .010 \\
\hline & $\mathrm{N}$ & 46 & 46 \\
\hline \multirow{3}{*}{$\begin{array}{l}\text { Subjective } \\
\text { Well Being }\end{array}$} & Pearson Correlation & $.376^{*}$ & 1 \\
\hline & Sig. (2-tailed) & .010 & \\
\hline & $\mathrm{N}$ & 46 & 46 \\
\hline
\end{tabular}

Hasil analisis ini menunjukkan Buruh adalah mereka yang bekerja terjadi hubungan yang cukup kuat antara pada usaha perorangan dan diberikan self esteem terhadap. Dikarenakan $p<0,05$ imbalan secara harian maupun borongan maka kesimpulan yang diperoleh adalah Ho diterima atau self esteem secara sesuai dengan kesepakatan kedua belah pihak, baik lisan maupun tertulis yang bersama-sama dapat memprediksi besarnya subjective well being. biasanya imbalan kerja tersebut diberikan secara harian. Kesehatan mental sangat terhubung dengan kesehatan fisik. 
Menurut Friedman (2010), menemukan keterhubungan antara stress dan kesehatan. Stress, dalam penelitian keduanya, menurunkan ketahanan tubuh, imunitas dan katahanan tubuh atas alergi tertentu. Penelitian tersebut turut mengungkap fakta menurunnya antibodi saat seseorang sedang berselera negatif pada situasi tertentu.

Ancaman stress dan gangguan psikologis lain mengancam buruh migran tidak hanya terkait dengan situasi kerja. Perbedaan kebudayaan dan situasi negara tempat bekerja adalah ancaman lain, selain kecemasan yang timbul akibat kekhawatiran terhadap keluarga yang ditinggalkan. Gejala psikologis stress dapat dirasakan dalam berbagai bentuk, seperti cemas, keinginan mengurung diri, kebosanan, kehilangan semangat hidup, menurunnya fungsi intelektual atau kognitif, lelah mental, bingung, marah dan sensitif.

Subjective well being dilihat dari bagaimana individu sendiri memandang positif dirinya, yaitu memahami peristiwa yang terjadi didalam kehidupannya sehingga memberikan tanggapan positif dalam penerimaan diri, hubungan sosial yang baik dengan sesama, mampu mengambil keputusan tanpa adanya tekanan dan campur tangan orang lain, memiliki keyakinan dan kompetensi dalam mengatur lingkungan, mempunyai komitmen dalam mengejar tujuan hidupnya, serta pribadi yang mempunyai locus of control.

Peningkatan subjective well being buruh sopir pengangkut peti kemas tidak lepas dari sistem yang dilakukan oleh perusahaan itu sendiri, kesadaran akan pentingnya subjective well being maupun efektivitas kerja produktif dapat dilaksanakan melalui berbagai cara seperti mempunyai visi dan misi yang sama yaitu untuk mendapatkan keuntungan yang banyak, mendengarkan pendapat dan aspirasi buruh, memberikan apresiasi kepada karyawan untuk meningkatkan kebahagian dan motivasi kerjanya, dan berkomunikasi dengan buruh untuk mendengarkan segala keluh kesahnya.

Dengan demikian pula hal nya dengan self esteem di PT. Tri Trans Wijaya Palembang. Self esteem dilakukan seperti jangan mengejar kesempurnaan. Bila buruh melakukan kesalahan, maafkanlah dan sekecil apa pun usaha mereka, jangan remehkan. Apa pun hal baik yang mereka lakukan, hargailah. Jangan sesali kekurangan mereka. Jadikan itu sebagai umpan balik untuk mengambil langkah-langkah yang lebih baik. Tapi kenyataannya, kondisi tersebut belum dapat terpenuhi secara optimal.

Dalam permasalahan dalam subjektive well-being pada pada buruh sopir pengangkut peti kemas PT. Tri Trans 
Wijaya Palembang, masih ada buruh sopir yang merasa rasa bersalah, khawatir dan cemas yang berlebihan, stress yang berlebihan ketika menghadapi masalah dijalan dan malu dan sedih dengan keluarga yang terlalu banyak tuntutan. Berdasarkan hasil penelitian dapat diketahui bahwa hasil kerja yang dicapai oleh buruh sopir pengangkut peti kemas PT. Tri Trans Wijaya Palembang dalam melakukan pekerjaan yang dibebankan padanya diukur melalui faktor yang terdiri dari penerimaan diri, hubungan positif dengan sesama, autonomi, penguasaan lingkungan,tujuan dalam hidup, dan pertumbuhan pribadi masih rendah.

Dalam hal ini self esteem di anggap sebagai salah satu faktor yang mempengaruhi subjektive well-being di samping faktor-faktor lainnya. Dari hasil penelitian ini terdapat ada hubungan antara yang sangat signifikan antara self esteem terhadap subjective well being pada buruh sopir pengangkut peti kemas PT. Tri Trans Wijaya Palembang.

Hal ini terbukti dari analisis data ditemukan koefisien korelasi antara antara self esteem terhadap subjective well being diperoleh sebesar $=0,375$ ( $\mathrm{r}$ hitung $=$ 0,375) $>\mathrm{r}$ tabel pada taraf signifikasi $(0,01<\alpha 0,05)$ artinya ada hubungan antara self esteem terhadap subjective well being pada Buruh sopir pengangkut peti kemas PT. Tri Trans Wijaya Palembang.
Berdasarkan hasil tersebut menunjukan bahwa self esteem terhadap subjective well being pada buruh sopir pengangkut peti kemas

PT. Tri Trans Wijaya Palembang ini menyumbangkan sebesar 37,5\%. Artinya kedua variabel memiliki keeratan hubungan, baik sumbangan self esteem terhadap subjective well being, maupun subjective well being terhadap self esteem. Sementara sisanya sebesar $62,5 \%$ merupakan sumbangan dari faktor lain yang mempengaruhi dan lebih besar pengaruhnya terhadap subjective well being. Hasil penelitian ini menunjukan bahwa pengaruh self esteem terhadap subjective well being pada buruh sopir pengangkut peti kemas PT. Tri Trans Wijaya Palembang, bila pengaruh subjective well being yang diberikan kurang baik maka respon yang diberikan akan berdampak terhadap self esteem buruh sopir pengangkut peti kemas. Subjective well being yang diberikan kepada buruh sopir pengangkut peti kemas yang akan menghasilkan harga diri seseorang.

Hasil penelitian menunjukan bahwa subjective well being adalah salah satu faktor penentu self esteem para buruh sopir pengangkut peti kemas yang memiliki masalah dalam subjective well being sehingga self esteem mereka menjadi menurun. Menurut Diener, 
definisi subjektive well-being yaitu sebagai penilaian hidup positif dan perasaan baik. Jadi individu dikatakan memiliki subjektive well-being yang tinggi jika individu sering mengalami kepuasan hidup dan kegembiraan, dan hanya sedikit mengalami emosi yang tidak menyenangkan seperti kesedihan atau kemarahan. Sebaliknya, individu dikatakan memiliki subjektive well-being yang rendah jika individu tidak puas dengan kehidupan, mengalami sedikit kegembiraan dan kasih sayang dan sering merasakan emosi negatif seperti kemarahan atau kecemasan (Larsen \& Eid, 2008).

Self esteem merupakan evaluasi yang dilakukan oleh individu pada dirinya sendiri dengan pandangan yang positif maupun sebaliknya mengahargai diri dengan cara negatif (Ghufron \& Risnawita, 2011). Begitu pula penelitian lainnya yang dilakukan oleh Lubis (2011) menunjukkan juga menunjukkan hal yang sama, bahwa self esteem sangat memegang peran penting dalam kehidupan seseorang. Selain itu, penelitian yang dilakukan oleh Rosenberg, Schooler, Schoenbach dan Rosenberg (1989) menguraikan bahwa global self esteem menjadikan sikap positif atau negatif pada individu kearah kesempurnaan diri. Jadi, dalam subjective well being sangat berhubungan erat dengan self esteem terhadap buruh sopir pengangkut peti kemas PT. Tri Trans Wijaya Palembang.

Hal ini jg terbukti dari skala self esteem dari 40 butir item yang disebarkan kepada para buruh sopir pengangkut peti kemas PT. Tri Trans Wijaya Palembang didapati sebanyak 36 item yang valid dengan koefisien validitas item-item tersebut berkisar antara 0,369 sampai dengan 0,712 dengan $r$ hitung $>r$ tabel 0,291. Untuk skala subjective well being yang disebarkan kepada buruh sopir pengangkut peti kemas PT. Tri Trans Wijaya Palembang didapati sebanyak 42 item yang valid dengan koefisien validitas item-item berkisar antara 0,315 sampai dengan 0,747 dengan $\mathrm{r}$ hitung $>\mathrm{r}$ tabel $=$ 0,291. Mengenai hal tersebut dapat disimpulkan bahwa self esteem ada hubungannya terhadap subjective well being pada buruh sopir pengangkut peti kemas PT. Tri Trans Wijaya Palembang kearah yang lebih baik lagi.

\section{SIMPULAN}

Berdasarkan analisis data ditemukan koefisien korelasi antara self esteem terhadap subjective well being ada hubungan antara self esteem terhadap subjective well being pada buruh sopir pengangkut peti kemas PT. Trans Wijaya Palembang. Berdasarkan hasil tersebut menunjukan bahwa self esteem terhadap subjective well being pada buruh sopir 
pengangkut peti kemas PT. Trans Wijaya Palembang ini menyumbangkan sebesar $37,5 \%$. Artinya kedua variabel memiliki keeratan hubungan, baik sumbangan self esteem terhadap subjective well being, maupun subjective well being terhadap self esteem. Sementara sisanya $62,5 \%$ merupakan sumbangan dari faktor lain yang mempengaruhi dan lebih besar pengaruhnya self esteem terhadap subjective well being pada buruh sopir pengangkut peti kemas PT. Trans Wijaya Palembang. 


\section{DAFTAR RUJUKAN}

Andrews, F. M., \& Withey, S. B. (1976). Social Indicators of Well-Being: America's Perception of Life Quality. New York: Plenum Press.

Badan Pusat Statistik. 2017. Data Sosial Ekonomi. Jakarta.

Baumeister, R.F. (1993), Self-esteem: The Puzzle of Low Self-regard, Plenum, New York, NY.

Brickman, P., \& Campbell, D. T. (1971). Hedonic relativism and planning the good society. In M. H. Appley (Ed.), Adaptation-level theory (pp. 287-305). New York: Academic Press.

Donnellan, M. B., Trzesniewski, K. H., Conger, K. J., \& Conger, R. D. (2007). Athree-wave longitudinal study of self-evaluations during youngadulthood. Journal of Research in Personality, 41 (2), hlm. 453-472.

Diener, E., Oishi, S., \& Lucas, R.E. (2003). Personality culture and subjective wellbeing: Emotional and cognitive evaluations of life. Annual Review of Psychology, 54, 403-425.

Eid, M dan Larsen, R. J. (2008). The Science of Subjective Well-Being. New York: The Guilford Press.

Eryilmaz, A. 2012. Mental Control: How do adolescents protect their subjective well being. The journal of Psychiatry and Neurilogical Science 25, 27-34.

Friedman, M. 2010. Buku Ajar Keperawatan keluarga : Riset,
Teori, dan Praktek. Edisi ke-5. Jakarta: EGC.

Ghufron \& Risnawita. (2011). Teori-Teori Psikologi. Yogyakarta: Ar-Ruzz Madia.

Rosenberg, M., Schooler, C., \& Schoenbach, C. (1989). SelfEsteem and Adolescent Problems: Modeling Reciprocal Effects. American Sociological Review, 54, 1004-1018. http://dx.doi.org/10.2307/2095720

Srivastava, R., \& Joshi, S. (2014). Relationship between Self-concept and Selfesteem in adolescents. International Journal of Advanced Research, 2 (2), 36-43.

Siedlecki, Karen L., Timothy A salthouse..shigehiro oishi \& Sheena Jeswani.2013. The Relationship Between Social Support and Subjet:tive Well-Being Acros Age. New York. Departement of psychology.

Sugiyono (2015). Metode Penelitian Kombinasi (Mix Methods). Bandung:Alfabeta.

Snyder, C.R \& Shane J. Lopez. 2002. Handbook of Positive Psychology. New York: Oxford University Press Inc.

Lubis, Ikhsan. 2011. Akuntansi Keperilakuan, cetakan kedua. Jakarta:Salemba Empat

Luhman, M., Eid M., Hofmann, W., \& Lucas, R. E. (2012). Subjective well-being and adaptation to life events: A meta-analysis. Journal of Personality and Social Psychology. 102 (3), 592-615. doi: $10.1037 / \mathrm{a} 0025948$. 
Orth, U., \& Robins, R. W. (2014). The development of self-esteem. Current Directions in Psychological Science, 23, 381 387.
Winarsih,Tri. 2006. Subjective wellbeing pada Wanita Menopause. Yogyakarta. UGM. 